\title{
Productivity Optimization in Rice-Based Intercropping Systems of Central Uganda
}

\section{Immaculate Mugisa ${ }^{1}$, Benard Fungo ${ }^{2}$, Stella Kabiri ${ }^{1}$, Godfrey Sseruwu ${ }^{1}$, Ruth Kabanyoro ${ }^{1}$}

\author{
${ }^{1}$ Mukono Zonal Agricultural Research and Development Institute, National Agricultural Research Organization (NARO), P.O. Box. 164, \\ Mukono, Uganda \\ ${ }^{2}$ National Forestry Resources Research Institute, National Agricultural Research Organization (NARO), P.O. Box. 1752, Mukono, Uganda
}

\begin{abstract}
Upland rice production in Central Uganda is mainly done by small scale farmers for both food security and income generation. However, they are faced with a number of challenges including drudgery, birds that eat the crop, erratic weather and limited land holdings. Due to the inadequate land available to them, upland rice has to compete with other food crops for land for cultivation. Thus, apart from the conventional mono-crop, alternative cropping systems that enable them to grow rice while simultaneously benefiting from other major food crops are quite desirable to them.

This study was conducted to identify suitable upland rice-based intercropping alternatives to enable upland rice farmers to benefit from intercropping. Three experiments were conducted for two consecutive seasons on rice-beans, rice-groundnuts and rice-maize intercrops, each as a randomized complete block design with 5 treatments and 3 replicates. Treatments for the rice-beans experiment included sole rice, sole beans, intercrop 1(rice:beans in ratio 3:2), intercrop 2 (rice:beans in ratio 4:2) and intercrop 3 (rice:beans in ratio 4:3). The same was done for experiments on the other two intercrops. Data were collected on plant height, tiller number, grain yield of rice and yield of the three intercrops at harvest. Results indicated that intercropping rice with the three crops leads to more yield benefits as observed from the land equivalent ratios (LERs) obtained (average 1.5).The best intercrop with better yields and higher LERs was intercrop 3 for the rice-legume mixtures and rice-based intercrop 1 for the rice-maize mixture.
\end{abstract}

Keywords - Rice, Beans, Groundnut, Maize, Intercrop.

\section{INTRODUCTION}

Rice is one of the crops that has the potential to improve farmers' incomes and livelihoods (JICA, 2009), thereby contributing to socio-economic growth of many rural farm households in Uganda. It is an important food security factor (UNRDS, 2009) and staple crop in many rural and urban households throughout the country (Oryokot et al., 2004). Rice is now widely grown in many parts of Uganda, particularly in the eastern and northern regions (Kijima et al., 2011). In the past, rice production in Uganda was mainly limited to irrigation schemes that had been established by the government in the 1960's and 1970's. However, with the introduction of upland rice in the early 2000's, the trend is changing as more small scale and a few large scale farmers take on the relatively new enterprise (UNRDS, 2009).

The production of upland rice in Uganda is still to a large extent done by resource poor farmers who hardly use external inputs. Therefore, the yields and consequently incomes from upland rice growing are still low compared to paddy rice (Defoer et al., 2004). In Central Uganda, the production of upland rice by small scale farmers in particular has been linked with challenges including erratic weather and droughts, birds that eat the crop at maturity, drudgery (particularly at planting, weeding and bird scaring) and theirlimited land holdings, where upland rice competes with food crops for land for cultivation. Most upland rice farmers are accustomed to monocultures as they've been trained, but they think that rice takes up land for long, depriving them of land for growing other important food crops like beans, maize, bananas and cassava (MUZARDI, 2013). Thus, they would wish to have an alternative cropping system that enables them to grow rice while at the same time benefiting from their usual food crops. The present system of mono-cropping has failed to meet the diversified domestic needs of small holder farmers from the 
dwindling supply of new lands for cultivation and other limited resources (Farrukh et al., 2000). These conditions necessitate a shift from mono-cropping to intercropping, which is considered as an excellent strategy for intensifying land use, absorbing excess labour and increasing income and production per unit area and time (Willey, 1979). Intercropping refers to the growing of two or more crops simultaneously on the same piece of land in alternate rows or set of rows (Zandstra, 1979). In India, rice intercropping practices have for a longtime been carried out. According to Mandal et al, 1990, intercropping provides farmers with profit and subsistence-oriented requirements from the same piece of land. This conclusion was drawn after a two-year experiment on intercropping rice and legumes to assess the effect of legumes on rice yields. Elsewhere in Nigeria, a study conducted on the rice-cowpea intercrop by Oroka and Omoregie (2007) revealed that nitrogen use efficiency is higher in intercrops than sole crops. In Nepal, a study was carried out to improve soil fertility and enhance productivity of upland rice varieties (Rokaya, 2004). In this study, upland rice varieties and legumes were grown in intercrops. Investigations indicated that continuous inclusions of legumes have positive impact on soil fertility, resulting in the sustainable productivity of upland rice.

Beyond its importance as a farming practice, intercropping often, offers the possibility of yield advantages relative to sole cropping through yield stability and improved yield (Willey, 1979). Contributors to yield advantages include; better use of growth resources (Trenbath, 1986) and better control of weeds, pests and diseases (Willey, 1979). It also helps to maintain soil fertility (Patra et al., 1986), making efficient use of nutrients (Ahmed \& Saeed, 1998) and ensuring economic utilization of land, labour and capital resources (Singh et al., 1996). Intercropping may be practiced for a number of yield goals, not limited to the production of dry matter (Willey, 1979). Morris and Garity (1993), for instance, stated that water use efficiency in intercropping was $18.99 \%$ higher than that in sole cropping. In a study that was conducted in Central Uganda in 2008 on factors affecting rice production in Semuto, Nakaseke District, $30.7 \%$ of the 150 rice farmers surveyed were found to be haphazardly intercropping rice with beans and maize despite their having been sensitized on rice growing as a mono-crop (MUZARDI, Unpublished).Farmers revealed that they were carrying out this practice in order to increase on their income, food security and to maximize the utilization of their small land holdings.

Since the conventional method of planting rice in monocultures does not permit intercropping, a study was initiated to identify suitable upland rice-based intercropping systems to ensure that farmers maximize the benefits of intercropping. Introducing other crops into the upland rice intercropping system would provide an opportunity for resource poor farmers to get cash from rice without entirely compromising on their food security. Moreover, in light of the current climatic changes and unreliable rainfall patterns, an upland rice farmer would not entirely make losses in case of crop failure due to unanticipated droughts but would still benefit from the secondary crop.

\section{MATERIALS AND METHODS}

\subsection{Study Area}

The study was carried out in Mukono (coordinates: $00^{0} 20^{\prime} \mathrm{N}$, $\left.32^{\circ} 45^{\prime} \mathrm{E}\right)$, Kayunga $\left(01^{0} \quad 00^{\prime} \mathrm{N}, 32^{\circ} \quad 52^{\prime} \mathrm{E}\right)$ and Kiboga $\left(01^{\circ} 00^{\prime} \mathrm{N}, 31^{0} 46^{\prime} \mathrm{E}\right)$ districts, all located within the Lake Victoria Crescent Agro-ecological Zone of Uganda.

\subsection{Experimental design}

Three experiments were conducted in 2013on selected ricebased intercrops: rice-beans, rice-maize and rice-groundnuts, for two consecutive planting seasons in 2013, each as a randomized complete block design (RCBD) with five treatments and 3 replicates. Treatments for the rice-beans experiment included sole rice, sole beans, intercrop 1(rice: beans, 3:2 rows), intercrop 2 (rice: beans, 4:2 rows) and intercrop 3 (rice: beans, 4:3 rows). The same was done for experiments on the other two rice-based intercrops: rice-maize and rice-groundnuts. The row-intercropping method was used and both rice and each of the intercrops were planted at the same time in different proportions in alternate rows (Fig.1). 


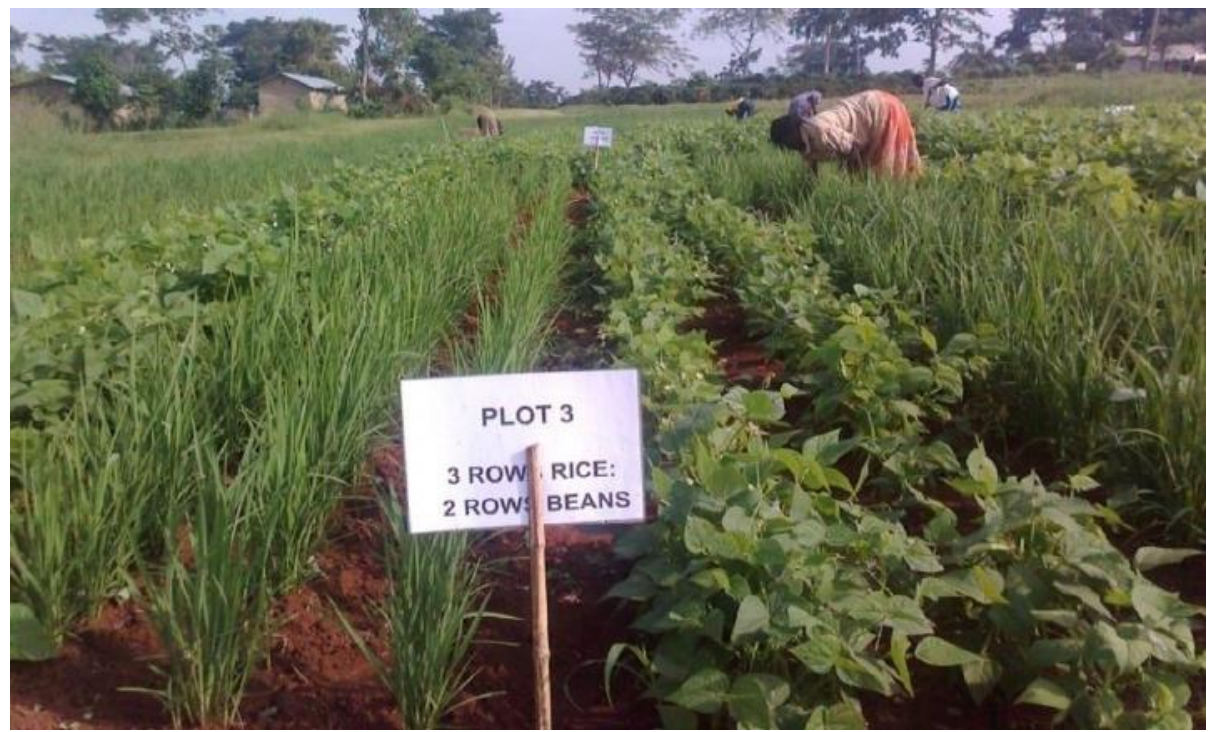

Fig.1: A trial field in Mukono district planted with the rice-beans 3:2 row intercrop

Upland rice variety NERICA 4 was used as the base (main) crop. A plot size of $8 \mathrm{~m} \mathrm{X} 5 \mathrm{~m}$ was maintained for each experimental unit. The rice seed was directly planted using the drilling method leaving a spacing of $30 \mathrm{~cm}$ between rows. All intercrops (beans, maize and groundnuts) were directly seeded with one seed per hill at a spacing of $45 \mathrm{~cm} \times 15 \mathrm{cmfor}$ groundnuts and beans and $75 \mathrm{~cm} \times 50 \mathrm{~cm}$ for maize. The wider spacing of the intercrop was always maintained between rows that bordered the rice. Prior to laying out the experiments, soil samples were taken from the trial sites for laboratory analysis to determine their baseline fertility status. The soil properties analyzed included organic matter content, $\mathrm{pH}$, total nitrogen $(\mathrm{N})$, phosphorus (P) and selected base cations ( $\mathrm{Ca}, \mathrm{Mg}$ and $\mathrm{K}$ ). Fertilizer application was then done using DAP (at 20 days after emergence (DAE)) and Urea (at 20 and 60 DAE). The trials were weeded twice during each season and were entirely rain-fed- no irrigation was done.

\subsection{Data collection and Analyses}

Data was collected on plant height, tiller number and grain yield of the rice crop. Data was also taken on yields of the intercrops i.e. beans, maize and groundnuts. At crop maturity, yields were obtained by harvesting the different crops within each net plot and extrapolating yields to $\mathrm{kg} / \mathrm{ha}$. This data was analyzed using GenStat statistical package (Genstat, 2010) to generate analyses of variance (ANOVA) to compare the yield differences of the different treatments.

The Land Equivalent Ration (LER), defined as the relative land area required as a sole crop to produce the same yields as intercrops, was obtained by using the following formula (Mead and Willey, 1980).

Where:

$$
L E R=P r+P b=\left[\frac{Y r}{S r}\right]+\left[\frac{Y b}{S b}\right]
$$

$P r$ and $P b=$ partial LER (rice and beans respectively) $Y r$ and $Y b=$ intercrop yields (rice and beans respectively)

$S r$ and $S b=$ yields of sole crops (rice and beans respectively).

An LER value of 1, signifies no advantage in intercropping as compared to sole cropping, whereas LER > 1 means a larger area of land is needed to produce the same yield of both sole crops of each component, in relation to intercropped mixture. An LER $<1.0$ shows a disadvantage of intercropping in comparison to mono cropping (Oroka and Omoregie, 2007; Kutrata, 1986).

One-way Analysis of Variance (ANOVA) was also used to test the difference in the mean LER among the treatments (at $P=0.05$ ). Descriptive statistics were used to characterize the different sites in terms of soil properties.

\section{RESULTS AND DISCUSSION}

\subsection{Yields and Land Equivalent Ratios}

Overall, analysis of variance of trial results revealed that there were no significant differences $(\mathrm{p} \leq 0.05)$ between the yields of rice planted in the different treatments (Table 1). However, there were significant differences $(\mathrm{p} \leq 0.05)$ in the yields of the 
various treatments for all the intercrops (maize, beans and groundnuts) (Table 2). The interaction between site, season and treatment was also significant $(\mathrm{p} \leq 0.05)$. This implies that the yield of rice was more or less similar in the various ricebased intercrops studied whereas the intercrop yields varied to a larger extent when intercropped with rice in different proportions. This could be attributed to the higher plant densities of rice compared to the intercrops considering the row intercrop ratios that were used in this study which all had more rows of the rice crop. A previous study carried out on a rice-cowpea intercrop by Oroka and Omoregie (2007) revealed that there was a response of rice yield to intercrop density such that higher densities of rice in cereal-legume intercrops do not substantially decrease its grain yield in comparison to intercrops with lower rice densities.

Table 1: Summary of ANOVA results for the yields of rice intercropped with three crops

\begin{tabular}{lcccc}
\hline $\begin{array}{l}\text { Source of } \\
\text { Variation }\end{array}$ & d.f & \multicolumn{3}{c}{ F-value } \\
\cline { 3 - 5 } & & Rice-maize & Rice-beans & Rice-groundnuts \\
\hline Season & 1 & $<0.001^{*}$ & $0.006^{*}$ & $<0.001^{*}$ \\
Site & 2 & $<0.001^{*}$ & 0.723 & $0.011^{*}$ \\
Treatment & 4 & 0.066 & 0.233 & 0.668 \\
Season*Site & 2 & 0.279 & 0.594 & $0.024^{*}$ \\
Season*Treatment & 4 & 0.898 & 0.638 & 0.878 \\
Site*Treatment & 8 & 0.919 & 0.366 & 0.987 \\
Season*Site*Treatment & 8 & 0.529 & 0.214 & 0.450 \\
Residual & 71 & & & \\
\hline
\end{tabular}

*Indicates significance at $\mathrm{p} \leq 0.05$

Table2: Summary of ANOVA results for the yields of intercrops

\begin{tabular}{lcccc}
\hline $\begin{array}{l}\text { Source of } \\
\text { Variation }\end{array}$ & d.f & \multicolumn{3}{c}{ F-value } \\
\cline { 3 - 5 } & & Maize & Beans & Groundnuts \\
\hline Season & 1 & 0.246 & $0.014^{*}$ & $<0.001^{*}$ \\
Site & 2 & 0.371 & 0.481 & $0.004^{*}$ \\
Treatment & 4 & $<0.001 *$ & $<0.001^{*}$ & $<0.001^{*}$ \\
Season*Site & 2 & 0.117 & $<0.001 *$ & $<0.001^{*}$ \\
Season*Treatment & 4 & 0.384 & 0.957 & 0.065 \\
Site*Treatment & 8 & 0.798 & 0.896 & 0.359 \\
Season*Site*Treatment & 8 & 0.659 & $0.011^{*}$ & $<0.001 *$ \\
Residual & 71 & & & \\
\hline
\end{tabular}

*Indicates significance at $\mathrm{p} \leq 0.05$

\subsection{Rice yields, Intercrop yields and Land Equivalent Ratios}

Yield results revealed that intercrop 1 (3:2 row intercrop), produced the highest yields of rice (Table 3), followed by the treatment of sole rice. It also produced the $2^{\text {nd }}$ highest number of tillers after the rice sole crop. However, it had the lowest plant height compared to all other treatments. The $2^{\text {nd }}$ best performing treatment in terms of average rice yields was intercrop 3 (4:3 row intercrop). 
Table 3: Summary of grand means of selected rice parameters in the four treatments

\begin{tabular}{|l|l|l|l|}
\hline $\begin{array}{c}\text { Treatment (plant proportions; } \\
\text { Rice: intercrop) }\end{array}$ & $\begin{array}{c}\text { Yields } \\
\text { (kg/ha) }\end{array}$ & $\begin{array}{c}\text { Plant height } \\
\text { (cm) }\end{array}$ & Tiller No. \\
\hline Intercrop 1 (3:2) & 2,560 & 34.6 & 10.12 \\
\hline Intercrop 2 (4:2) & 2,058 & 38.7 & 9.88 \\
\hline Intercrop 3 (4:3) & 2,134 & 39.8 & 10.07 \\
\hline Sole rice & 2,357 & 36.2 & 11.3 \\
\hline
\end{tabular}

In the rice: maize trial, intercrop 1 (3:2 row intercrop) produced the highest maize yields, followed by intercrop 3 and 2 respectively. For the case of beans and groundnuts, intercrop 3 produced the highest yields followed by intercrops 1 and 2 respectively (Fig.2). These results reveal that intercrop 3 (4:3 row intercrop) is the best performing in terms of rice yields for row intercropping of rice with beans and groundnuts whereas intercrop 1 produces higher rice yields for the case of rice: maize row intercropping. The generally low average yields obtained for both rice and the intercrops could be due to the low precipitation that occurred in the study areas during the $2^{\text {nd }}$ planting season of the study since the trials were rain-fed and not irrigated. Furthermore, it could also be due to the very low values of nitrogen (below critical values- as revealed by the soil analysis results in Table 4) at the trial sites despite the urea that was applied during the course of the study.

Results of LER revealed that overall, intercropping rice with beans, ground nuts or maize, yields more than each of the crops grown alone (Fig.3), implying an advantage of intercropping over mono-cropping, thus better resource use efficiency by the crop mixture.

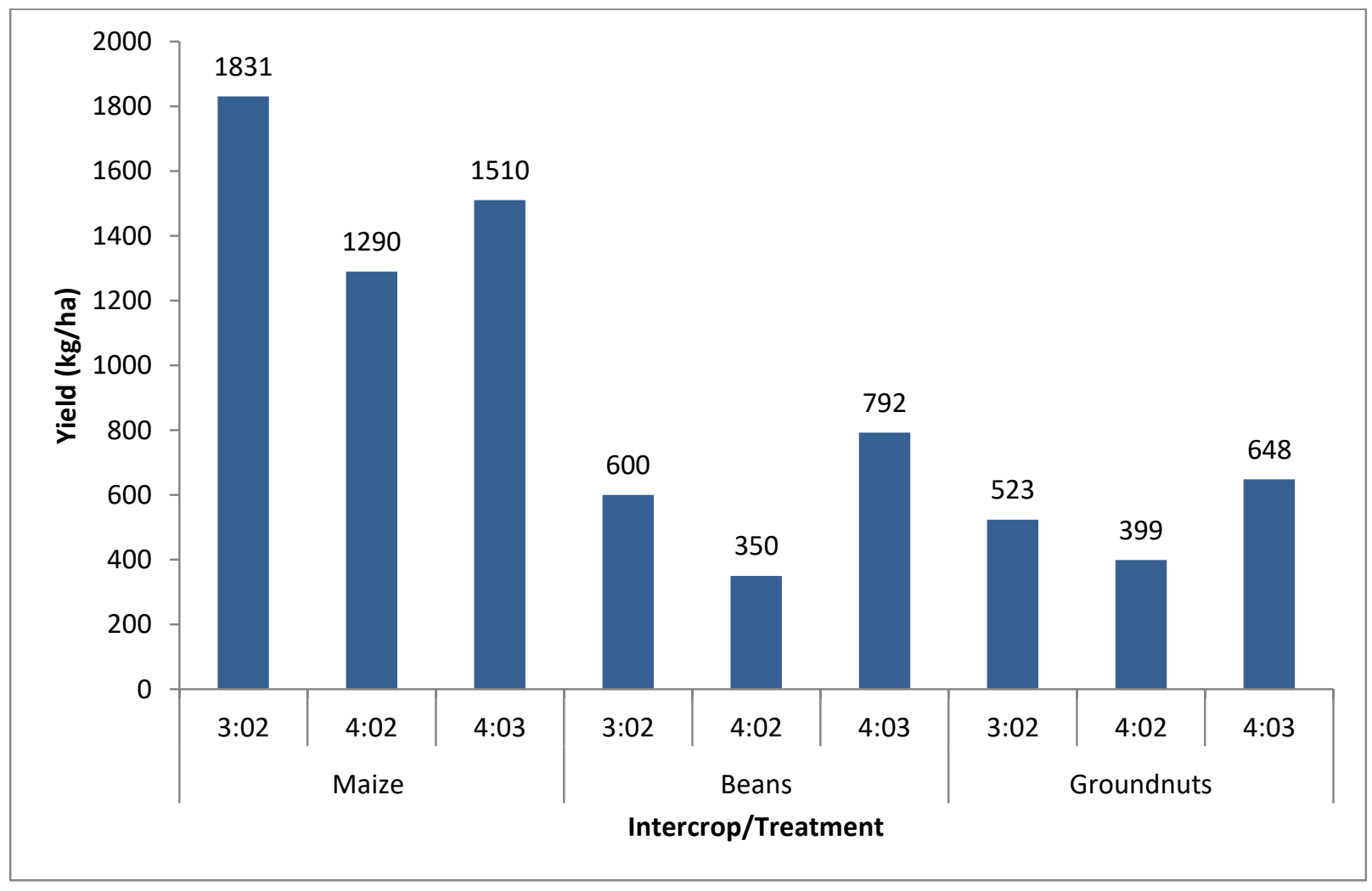

Fig.2: Mean yields of intercrops in treatments $(\mathrm{kg} / \mathrm{ha})$ 


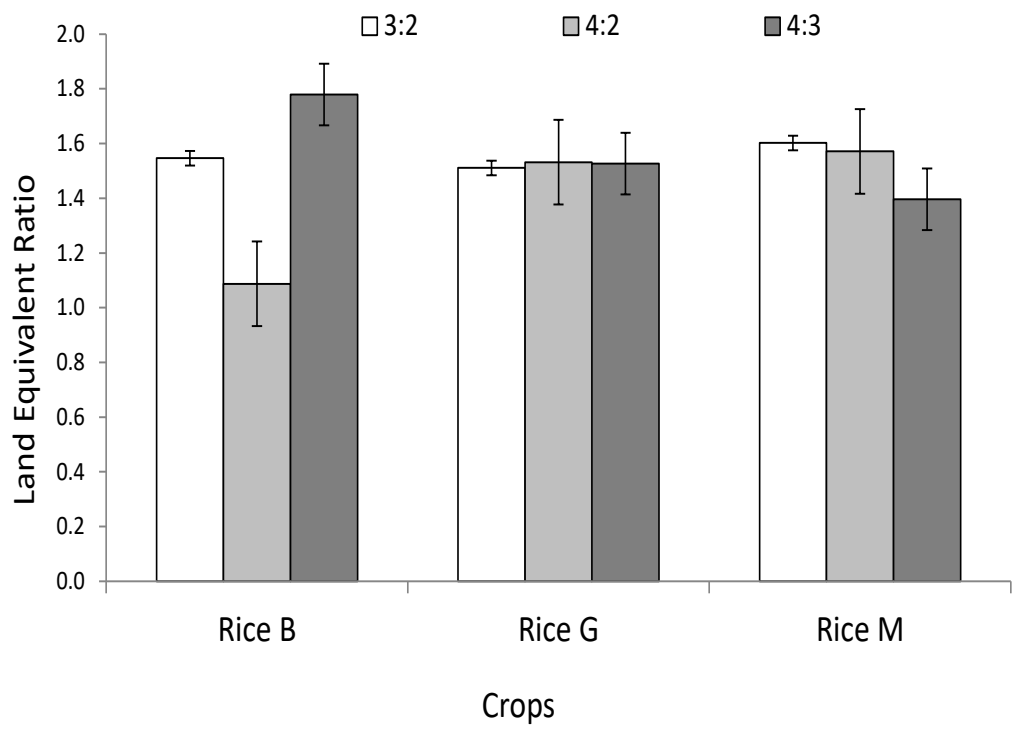

Fig.3: Overall LERs of intercrops

Rice B, Rice G and Rice M represent Rice intercropped with Beans, Groundnuts and Maize respectively. R:X indicates number of rice: intercrop rows, respectively

LER measures the levels of intercrop interference going on in the cropping system. A total LER higher than 1.0 indicates that the presence of positive inter-specific interference that exists in the mixture is not as intensive as the inter-specific interference that exists in the monoculture (Dariush, et al., 2006). An LER value of 1.0 indicates no difference in yield between the intercrop and the monocrop and any value greater than 1.0 indicates an advantage for the intercrop. An LER of 1.2 , for instance, indicates that the area planted with the monocrop would need to be $20 \%$ greater than the area planted with intercrop for the two to produce the combined yield (Kutrata, 1986).The average value of LER obtained (1.5) across intercrops in both seasons indicates that on average approximately 1.5 times more land is required to produce the same yield of the sole crops compared to that of the intercrops. Values of LER $>1$ were obtained in another study on rice based intercrops in Nigeria by Oroka and Omoregie (2007) where a yield advantage of intercropping at all levels of nitrogen and plant densities were reported for a rice-cowpea mixture with yield advantages ranging from LER 1.79 to 2.30. The rice-beans and rice-groundnuts intercrop, both produced better yields and higher LERs under intercrop 3 (4:3 row intercrop) which had higher intercrop densities compared to intercrop 2 (4:2 row intercrop) and intercrop 1 (3:2 row intercrop). This yield advantage could be attributed to more efficient utilization of light, water and nutrients during the growing season considering that the legumes are much shorter than the rice. Beans in particular have a shorter life cycle compared to rice, which must further have contributed to its best performance in terms of LER. Differences in growth cycles between crops has been reported to be important in intercropping because they enable more efficient water and nutrient utilization during the growth period (Willey and Osiru, 1972).

In a rice-cassava intercrop study that was done in Sierra Leone (Dahniya et al., 1994), it was reported that a higher intercrop density leads to lower values of LER and vice versa. For the case of this study, this was only observed in the rice- maize trial where higher densities of maize in intercrop 3 (4:3 row intercrop) led to a lower LER whereas the lowest maize density intercrop gave the highest LER. This could also be attributed to the less efficient light, water and nutrient utilization by the two crops which are both tall and take about the same time to mature in the field since these trends were the opposite for the rice-beans and rice-groundnuts intercrop.

\subsection{Soil Properties of study sites}


Table 4: Soil properties of the three experimental sites

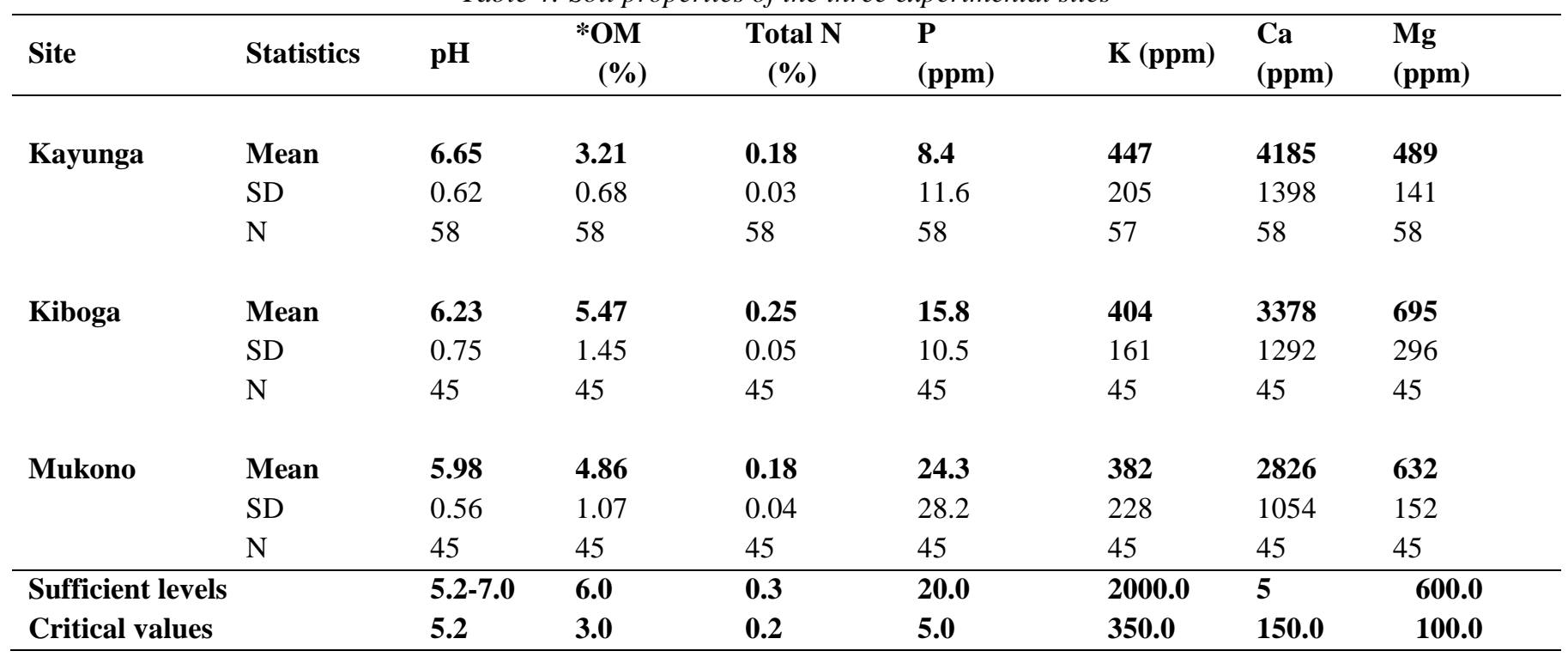

* OM= Organic Matter

Soil $\mathrm{pH}$ of all the sites was within the optimum range required for most crops. Organic matter (OM) content was above critical limits but also below sufficient level for all the sites. The macro-nutrients nitrogen, phosphorus and potassium were at or below critical limits for all the sites. That notwithstanding, the macro-nutrients $\mathrm{Ca}$ and $\mathrm{Mg}$ were not limiting.

The low level of OM reflects the combination of high degradability associated with high temperature conditions prevalent in the tropical region, as well as the relatively low level of OM inputs by farmers. This is due to the tendency for farmers to remove biomass residues from crop fields during harvesting without replacing it. The biomass is often used as either feedstock or burnt during land clearing for subsequent seasons. The major macro-nutrients ( $\mathrm{N}, \mathrm{P}$ and $\mathrm{K})$ are those usually consumed in large quantities and can easily be replaced through commercial synthetic fertilizers. The exceeding low level of nitrogen at the trial sites could have contributed to the low yields despite the blanket application of urea during the course of the study.

\section{CONCLUSIONS AND RECOMMENDATIONS}

The results of the present study revealed that intercropping rice with beans, ground nuts or maize, yields more than each of the crops grown alone as shown by the LER values obtained. On average approximately 1.5 times more land is required to produce the same yield of the sole crops compared to that of the intercrops. Furthermore, it was observed that the yield of rice was more or less similar in the various rice-based intercrops studied whereas the intercrop yields varied to a larger extent when intercropped with rice in different proportions. It can be concluded therefore that using higher plant densities of rice in comparison to the intercrop will more or less not affect the rice yields obtained. We therefore recommend that small holder farmers who are interested in rice intercropping utilize higher ratios of rice compared to intercrop using the row intercropping method.

An analysis of the three rice- based intercrops studied showed that the best row intercrop the rice-beans and rice-groundnuts mixtures was intercrop 3 which had a planting ratio of $4: 3$ (rice: intercrop) and produced both better yields and higher LERs. However, for the case of rice-maize, intercrop 1 with a planting ratio of 3:2 (rice: maize) performed best. We therefore recommend the 4:3 row intercrop ratio for rice-based intercrops with beans and groundnuts whereas $3: 2$ is preferable for rice-maize intercrops. This would ensure enhanced yields and ensure food security among smallholder upland rice farmers as a result of improved nutrient, light and water use efficiency in these intercrops.

Soil productivity in rice based intercrops is mainly limited by low nitrogen, phosphorus, potassium and organic matter. In order to improve soil productivity, the application of mineral fertilizer such as NPK is recommended. Farmers are also advised to retain crop residues and/or employ biomass transfer systems (manure, plant residues from their places into the gardens) in order to increase the level of soil organic matter. 
Through. Finally, extension education on appropriate row intercropping and fertility management practices would also help optimize nutrient use efficiencies from fertilizer use in the recommended intercrops.

\section{ACKNOWLEDGEMENTS}

This work was funded by the World Bank under the Agricultural Technology and Agribusiness Advisory Service (ATAAS) project implemented by the National Agricultural Research Organization. We are very grateful for this support. We appreciate all staff of MUZARDI who were involved in data collection including George Kituuka, Robinah Gafabusa, Barbara Kyampeire, Maria Nampeera, Robert Mutyabaas well as staff of Kiboga and Kayunga District Local Governments for their collaboration during the entire course of this study.

\section{REFERENCES}

[1] Ahmad, N. and Saeed, M. 1998. Resource-use efficiency of some wheat based intercropping systems at different patterns of wheat plantation. Pakistan Journal of Agricultural Science, 35:52-4

[2] Dahniya, M.T., Jalloh, A. and Ezumah, H.C. 1994. Intercrop yields of cassava and rice as influenced by cassava variety and population. In: Ofori, F.; Hahn, S.K. (Ed.). Root crops in a developing economy. Ibadan: International Institute for Tropical Agriculture, p.194-199.

[3] Dariush, M., Ahad, M. and Meysam, O. 2006. Assessing the land equivalent ratio (LER) of two corn (Zea mays L.) varieties intercropping at various Nitrogen Levels in Karaj, Iran. Journal of Central European Agriculture. 7(2) 359- 364.

[4] Defoer, T., Wopeires, M.C.S., Jones, M.P., Lanson, F., Erenstein, O. and Guei, G.R. 2004. Challenges and technical opportunities for rice based production systems for food security and poverty alleviation in sub-saharan Africa. FAO Rice Conference.

[5] Farrukh, S.M., Shamshad, H., Asghar, M. and Kashif, M. 2000. Bio-Economics of different upland rice-based intercropping systems under strip plantation. International journal of agriculture and biology. Vol 2., No. 4: pp: 294-296.

[6] Genstat, 2010. Genstat Thirteenth Edition, Procedure Library Release PL21.3. Lawes Agricultural Trust, Rothamsted Experimental Station. Clarendon Press, Oxford.

[7] Jalloh, A., Dahniya, M.T. and Ezumah, H.C. 1994. Production of cassava-rice intercrop as influenced by cassava variety and time of introducing rice into cassava.Acta Horticulturae. 380, 200-204. DOI: 10.17660/ActaHortic.1994.380.30

[8] JICA. 2006. Japan International Cooperation Agency, (JICA) In collaboration with Sasakawa Africa Association Uganda. Final Survey Report on the status of rice production, processing and marketing in Uganda. Available on: https://www.mofa.go.jp/mofaj/gaiko/oda/bunya/agriculture/pd f/uganda report.pdf (Accessed: $21^{\text {st }}$ Dec. 2018)

[9] Kijima, Y., Otsuka, K. and Sserunkuuma, D. 2011. An inquiry into constraints of a green revolution in Sub-Saharan Africa: The Case of NERICA rice in Uganda. World Development. Vol. 39, No. 1, Pp. 77-86.

[10] Kutrata, T. 1986. A study on farming systems in USSA. Quarterly. J. Agro. Eco. 26: 179- 205.

[11] Mead, R. and Willey, R. W. 1980. The concept of land equivalent ratio and advantages. Experimental Agriculture. 16: 217- 226.

[12] Morris, R.A and Garrity, D.P. 1993. Resource capture and utilization in intercropping: non-nitrogen nutrients. Field Crop Research. 34:319-34.

[13] MUZARDI. 2013. Mukono Zonal Agricultural Research and Development Institute. Annual Report. 2013.

[14] Oryokot, J., Forster, M., Kayayo, B. and Pookat V. 2004. Private/Public sector partnerships in sustainable development and promotion of rice for improved farm household income in Uganda. Unpublished Paper Presented at the "Year of Rice Conference", Uganda.

[15] Patra, D.P.,Sachdev,M.S. and Subbiah, B.V. 1986. Nitrogen fixation by tropical elements. Fertil.Soils, 2: 165-71.

[16] Rokaya, B. B. 2007. Productivity improvement in upland rice through the inclusion of legumes, in far-western mid-hill areas of Nepal. 5th International Crop Sci. Congress, 10-15 September 2007, Adelaide, South Africa.

[17] Singh, G., Singh, O.P., Kumar, M., Rajput,A.L. and Maurya, S. 1996. Effect of intercrops on yields and economics, weeds and pest infestation of deep water rice. Annals of Agricultural Research. 17:14-17.

[18] Trenbath, B.R. 1986. Resource use by intercrops. In. Multiple cropping systems. C.A. Francis. MacMillan Pub. Co., New York, pp: 57-81.

[19] UNRDS. 2009. Uganda National Rice Development Strategy. 2nd Draft. Ministry of Agriculture Animal Industry and Fisheries. Available from: https://www.jica.go.jp/english/our_work/thematic_issues/agri cultural/pdf/uganda_en.pdfAccessed: $21^{\text {st }}$ Dec. 2018)

[20] Willey, R.W. 1979. Intercropping- its importance and research needs. 1. competition and yield advantages. Field crop Absts., 32: 1-10.

[21] Willey, R.W. and Osiru, D.S.O. 1972. Studies on mixture of maize and beans (Phaseolus vulgaris) with particular reference to plant population. Journal of Agricultural Science, v.77, p.531- 540 .

[22] Zandstra, H. G. 1979. Terminologies in cropping systems "Definitions and Parameters"- Lecture notes of six month cropping systems training programme at IRRI, Philippines. 